RESEARCH ARTICLE

(D) Selcuk Akturan ${ }^{1}$

(D) Omer Karahan ${ }^{2}$

D Mehmet Akman 3

\author{
${ }^{1}$ Karadeniz Technical \\ University, Faculty of Medicine, \\ Department of Medical \\ Education, Trabzon, Turkey \\ 2 Tercan State Hospital, \\ Erzincan, Turkey \\ ${ }^{3}$ Marmara University, Faculty of \\ Medicine, Department of Family \\ Medicine, Istanbul, Turkey
}

Corresponding Author:

Mehmet Akman

Marmara University, Faculty of

Medicine, Department of Family

Medicine, Istanbul, Turkey

Phone:+90 5326066848

mail:makman4@gmail.com

Received: 26.11.2020

Acceptance: 25.06 .2021

DOI: $10.18521 / \mathrm{ktd} .831767$

Konuralp Medical Journal e-ISSN1309-3878

konuralptipdergi@duzce.edu.tr konuralptipdergisi@gmail.com www.konuralptipdergi.duzce.edu.tr

\section{The Prevalence of Multimorbidity Among Adults Aged 40 Years and Above in Primary Care Setting: A Cross-Sectional Study}

ABSTRACT

Objective: Coordination function of primary care (PC) enables continuous, efficient, and costeffective health care provided to patients with chronic disease and multimorbidity (MM). The aim of this study was to identify the most common chronic diseases and to determine the prevalence of MM in PC registries.

Methods: Our study is a cross-sectional study. All the individuals aged 40 and over who were registered to the primary care units (PCUs) of the Uskudar district of Istanbul have formed the population of the study. A systematic cluster sampling was used. The patient list of each family physician in Uskudar district was accepted as a cluster and an equal number of patients from each cluster were enrolled. Only the information on the patients' MM data was requested from the primary care physicians.

Results: The 108 physicians of the Uskudar district (response rate: 73.4\%) gave consent to participate in the study. The $1187(40.3 \%)$ of registered patients of all PCUs were 40 years old and over. The multimorbid patients were found as $330(27.8 \%)$.

Conclusions: Approximately, one of four patients have multimorbidity. So, the policy of primary care services should be redesigned for the management of MM patients including the 'goal-oriented care' approach.

Keywords: Multimorbidity, Physicians, Primary Care, Prevalence, Health Policy.

\section{Birinci Basamakta 40 Yaş Ve Üzeri Yetişkinlerde Multimorbidite Prevalansı: Kesitsel Bir Çalışma ÖZET}

Amaç: Birinci basamağın (BB) koordinasyon işlevi, kronik hastalığı ve multimorbiditesi (MM) olan hastalara sağlanan sağlık hizmetlerinde sürekli, verimli ve uygun maliyetli sağlık bakımını sağlar. $\mathrm{Bu}$ çalışmanın amacı $\mathrm{BB}$ kayıtlarında en sık görülen kronik hastalıkları ve MM prevalansını belirlemektir.

Gereç ve Yöntem: Çalışmamız kesitsel bir çalışmadır. İstanbul'un Üsküdar ilçesine bağlı Aile Sağlığı Merkez'lerine (ASM) kayıtlı 40 yaş ve üzerindeki tüm bireyler çalışmanın evrenini oluşturmuştur. Örneklemin seçiminde sistematik küme örneklemesi metodu kullanılmıştır. Üsküdar ilçesindeki her aile hekiminin hasta listesi küme olarak kabul edilmiş ve her kümeden eşit sayıda hasta kaydedilmiştir. Birinci basamak hekimlerinden sadece hastaların MM verileri ile ilgili bilgiler istenmiştir.

Bulgular: Üsküdar ilçesinin 108 hekimi (yanıt oranı:\% 73,4) çalışmaya katılmayı kabul etmiştir. Tüm PKB'lerde kayıtlı hastaların 1187'si (\% 40,3) 40 yaş ve üzerindeydi. Multimorbid hastalar $330(\% 27,8)$ olarak bulunmuştur.

Sonuç: Yaklaşık olarak dört hastadan biri multimorbiditeye sahiptir. Bu nedenle, BB sağlık hizmetleri politikası, MM hastalarının yönetimi için "hedefe yönelik bakım" yaklaşımı dahil olmak üzere yeniden tasarlanmalıdır.

Anahtar Kelimeler: Multimorbidite, Birinci Basamak, Hekim, Sağlık Politikası, Prevalans. 


\section{INTRODUCTION}

The World Health Organization (WHO) defined 'multimorbidity' (MM) as the presence of two or more chronic diseases simultaneously in the same individual (1). MM was also defined as any combination of chronic disease with at least one other disease (acute or chronic) or bio-psychosocial factors (associated or not) or somatic risk factors by The European General Practice Research Network (EGPRN) (2).

The biggest challenge in dealing with MM is the definition of chronic disease. There are also different definitions for chronic disease. WHO defines the chronic disease as a health problem requiring follow-up or treatment for many year (3). According to ICPC-2 (International First Step Classification-2), chronic disease has a pattern of recurrence or worsening for at least 6 months that is expected to continue, with a poor prognosis, which may lead to consequences or sequelae that may affect the quality of life of the person (4).

Family medicine, with its holistic, person centred and comprehensive approach, plays an important role in the management of chronic diseases. Especially, coordination function of primary care enables continuous, efficient and cost effective health care provision to patients with chronic conditions. Also, it is important to know the prevalence of MM to develop and improve health policy for primary care (5).

Barnett et al. found MM prevalence as $23.2 \%$ among registered patients and the prevalence of $\mathrm{MM}$ increased substantially with age and was present in most people aged 65 years and older (6). Prevalence of MM was reported as between $14.5 \%$ and $29.0 \%$ in primary care settings (7). In Dutch study, the MM data was collected from family medicine registries and the prevalence was reported as $34.7 \%$ among $40-59$ years old, $63.1 \%$ among 60-79 years old, and $78.2 \%$ among $80+$ years old (8). In Turkey, we have some data regarding individual prevalence of major chronic diseases like diabetes prevalence from The Turkish Diabetes Epidemiology Study (TURDEP), to our knowledge, there is no data regarding MM prevalence of the registered population to primary care units (PCUs) $(9,10)$.

The aim of this study was to identify the most common chronic diseases and to determine the prevalence of $\mathrm{MM}$ in the older than 40 years population enrolled in the PCUs in Uskudar district of Istanbul in primary care registries.

\section{MATERIAL AND METHODS}

Our study is a cross-sectional study. In a systematic review of MM prevalence, Fortin et al. found that the prevalence of $\mathrm{MM}$ in individuals aged 40 years and older showed a sharp increase compared to under 40 years of age (11). Therefore, all the individuals aged 40 and over who were registered to the PCUs of the Uskudar district of Istanbul have formed the population of the study.
Our study was conducted between 04/31/2015 $08 / 31 / 2015$. In the district of Uskudar, a population of 40 years and over was identified as 208964 persons who registered to PCUs. In order to represent the research population, with $95 \%$ confidence level and 3\% standard deviation, the estimated sample size was 893 .

A systematic cluster sampling was used. The patient list of each family physician in Uskudar district was accepted as a cluster and an equal number of patients from each cluster were enrolled. There were 147 primary care physicians (PCPs) in the Uskudar district. In order to reach 893 patients with a presumption of $60 \%$ of physicians' participation into the study, 11 patients from the patient registration list of each PCP were randomly selected using the national identification numbers of the patients. Online program called 'Research Randomizer' was used for randomization (12). PCPs accepted to participate in the study were in charge of the randomization process and sent the requested data from the patient records anonymously to the researchers.

Only the information of the patients' MM data was requested from the family physicians. In our study, we used the definition of Julie O'Halloran et al. and the definition of WHO for $\operatorname{MM}(1,4)$.

The database used in primary care in Turkey includes all state (including primary care) and private outpatient visits of the patients. The type of visit (primary or secondary care) and diagnosis were the main variables gathered from the data provided by PCPs. The researchers visited each PCU at least 2 times during the study period. Patients, who could not be reached due to reasons such as off day and sickness, absence during these two visits, were not included in the study. Patients of PCPs refused to participate in the study were also excluded.

Our study was approved by Marmara University Institute of Health Sciences Ethics Committee. (Date/Protocol number: 29.04.201520/60)

SPSS 16.0 program was used to analyze the data. Firstly, descriptive statistics (percentage, mean standard deviation, etc.) of the data were calculated. Then, in the comparative analysis, chisquare was used to test the difference between the two groups and the t-test was used for the significance of the difference between the two means. The p-value $<0.05$ was considered significant.

\section{RESULTS}

108 PCPs (response rate: $73.4 \%$ ) gave consent to participate in the study and share their patients' characteristics and diagnosis (Fig 1). The 40 years and over ages registered patients of all PCUs were determined as 1187 (40.3\%). 


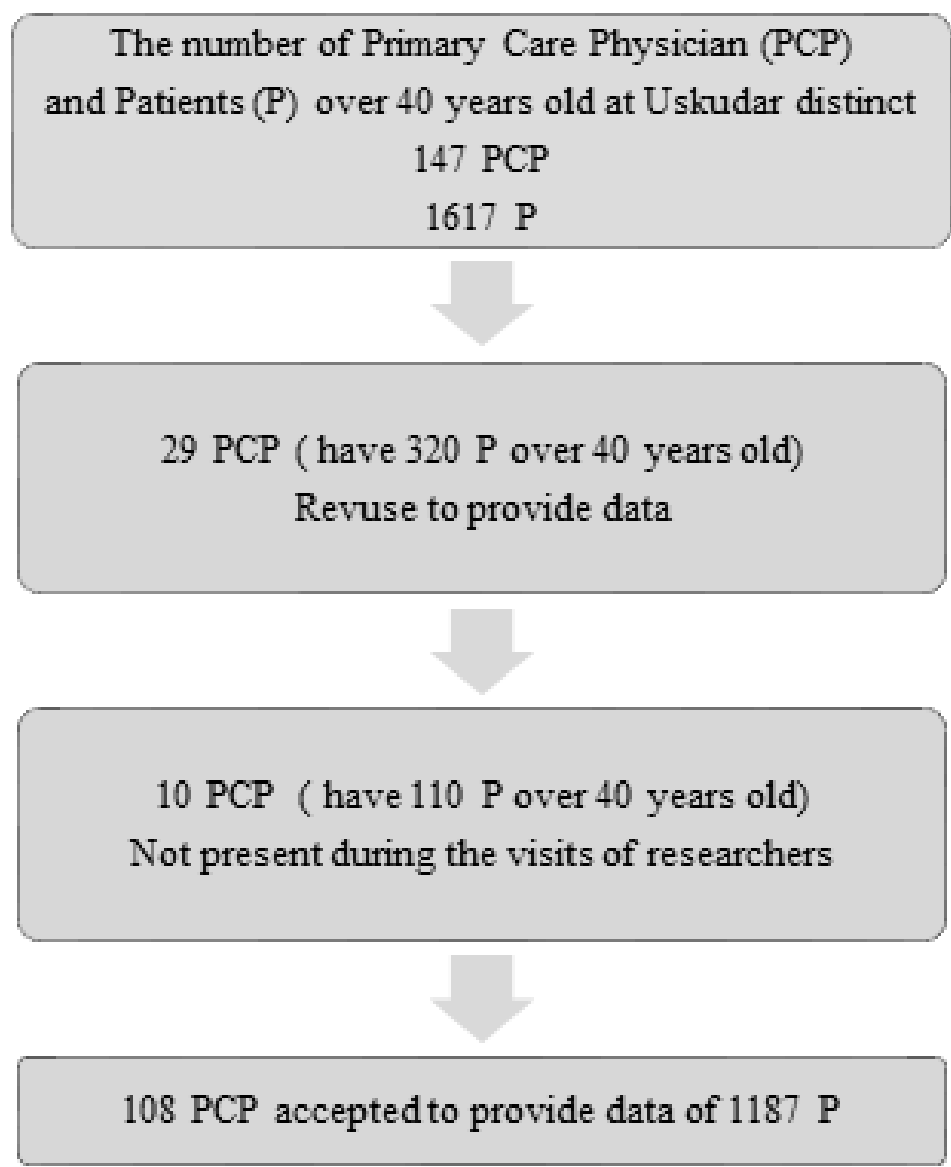

Figure. 1. Flow charts for participation status of primary care physicians

Among the 1187 patients, 596 (50.2\%) were female and $591(49.8 \%)$ were male. The mean age was $55.5 \pm 12.2$ years $(56.6 \pm 12.4$ years for female, $54.4 \pm 11.9$ years for male). The $917(77.4 \%)$ of the patients were under 65 years of age and 267 $(22.6 \%)$ of them were 65 years and above.
Considering all the participants, the MM patients were found as $330(27.8 \%)$. The prevalence of MM among women was significantly higher than the men. Additionally, the prevalence of MM in patients aged 65 years and older was significantly higher than below 65 years old (Table 1 ).

Table 1. Prevalence of multimorbidity distribution by gender and age of 65 years

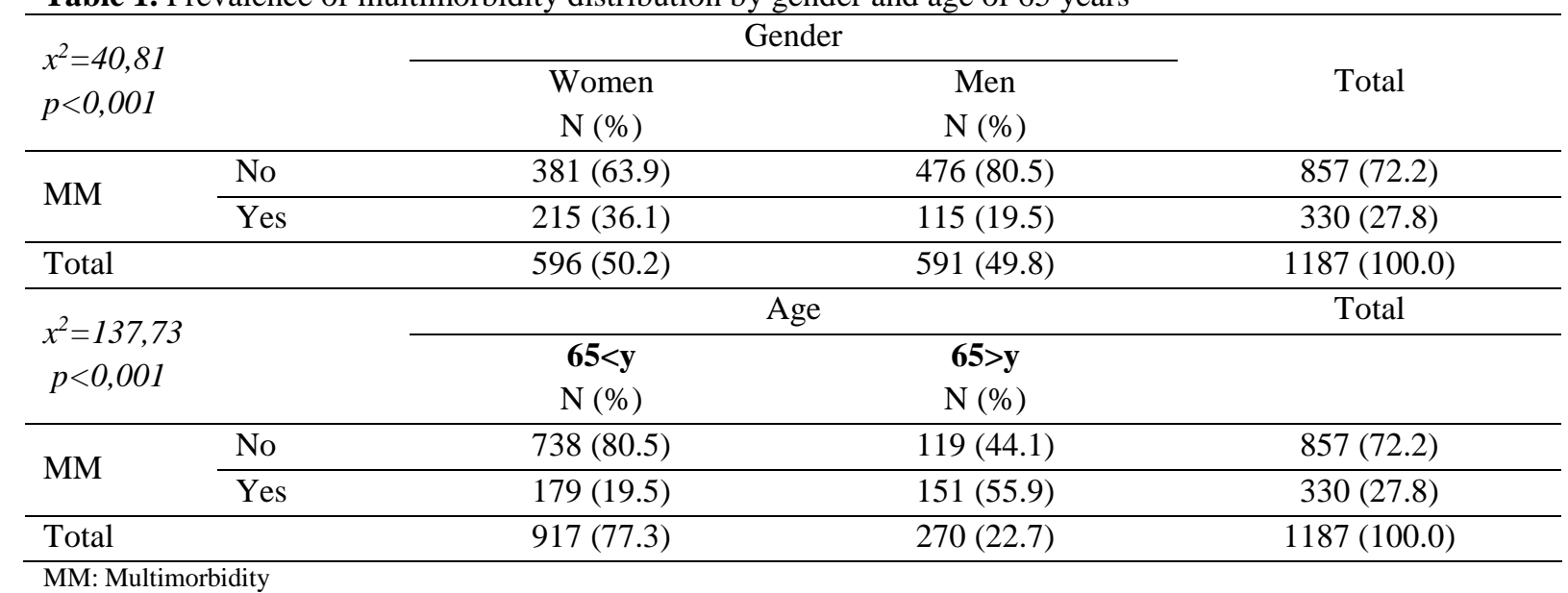

Patients with MM had significantly more visits to PCUs and hospitals within a year compared to their peers without MM. (PCU: $t: 26,13 p<0,001$; Hospital $t: 11,30 p<0,001)$

There was a significant relationship between age and chronic disease number, shown on Table 2 . There was no significant relationship for gender and number of chronic diseases $(p>0.05)$. 
Table 2. Prevalence of multimorbidity distribution by gender and age of 65 years

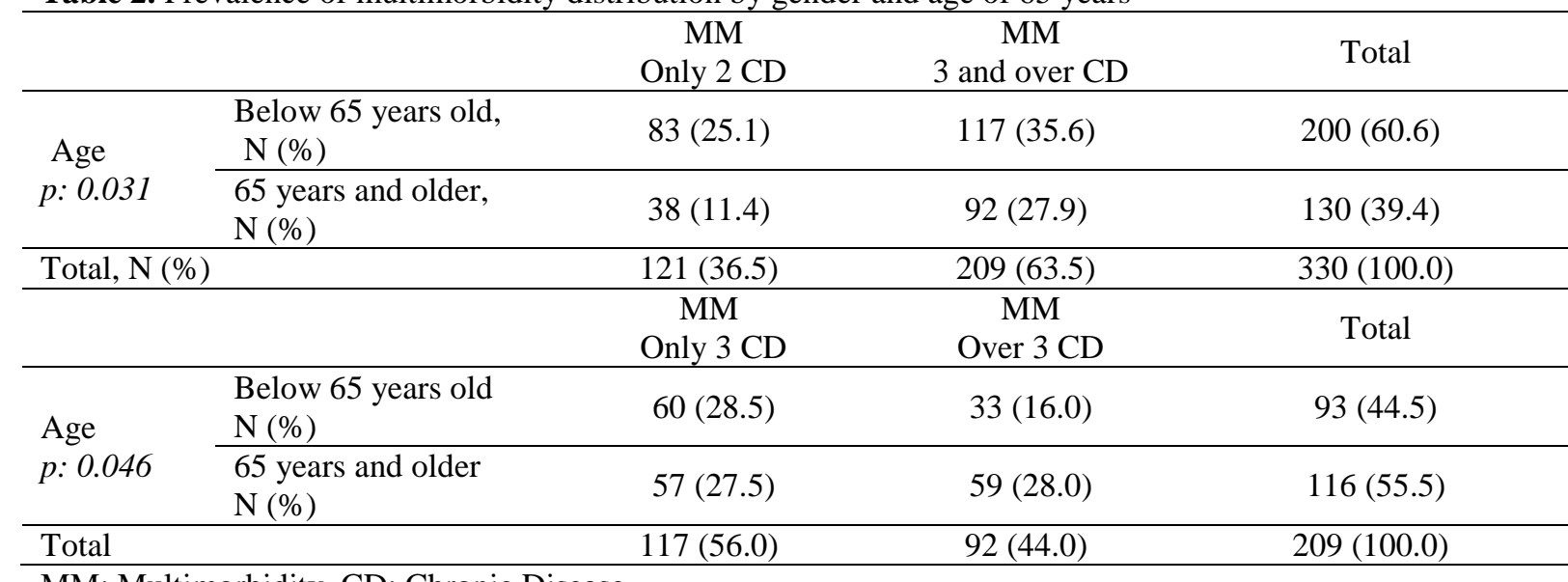

MM: Multimorbidity, CD: Chronic Disease

While $519(43.7 \%)$ of the participants had at least 1 chronic disease, women were 340 (57.0\%) and men were $179(30.3 \%)$. No any chronic disease was detected in $602(65.6 \%)$ of individuals under 65 years of age. This rate falls to $63(23.6 \%)$ in 65 years and older.
The most common disease in our study was hypertension found in $318(26.8 \%)$ patients. The second one was diabetes mellitus observed in 130 $(11 \%)$ and the third one was depression as 90 (7.6\%) (Fig 2).

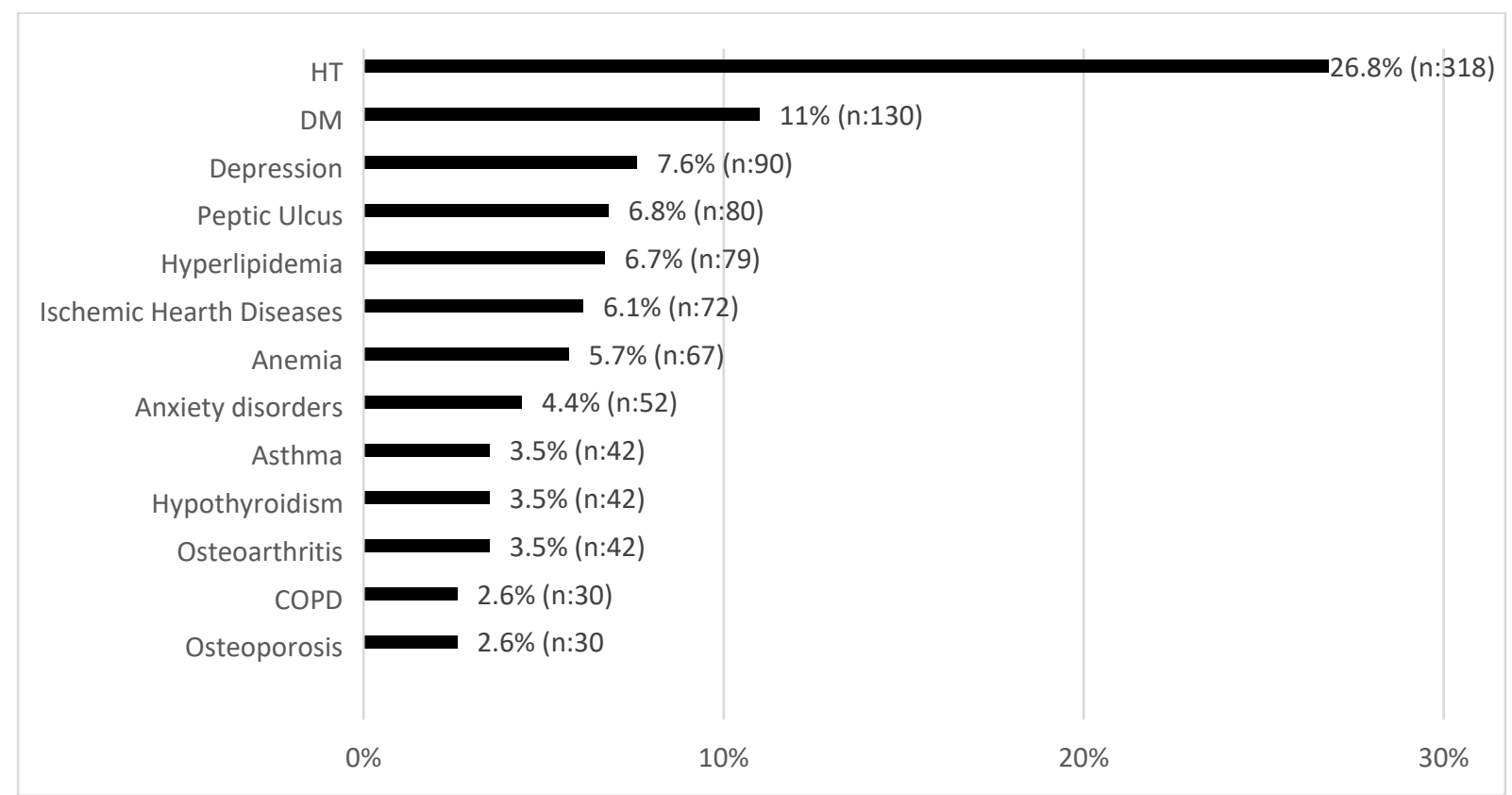

Figure 2. The most common chronic diseases seen on multimorbidity patients

In women, the most common diseases were: hypertension $202(33.9 \%)$, diabetes mellitus 85 $(14.3 \%)$ and depression $64(10.7 \%)$. In men, that was the most important difference between women and the general population, depression was not included in the first 3 most common diseases, and ischemic heart disease was located in the $3 \mathrm{rd}$ place.

A dramatic increase in the prevalence of hypertension was observed in patients aged 65 and older. In patients aged 65 years and older, the prevalence of hypertension was $168(62.9 \%)$, the prevalence of diabetes was $57(21.3 \%)$, and the prevalence of ischemic heart disease was 46 $(17.2 \%)$

\section{DISCUSSION}

In our study, the prevalence of MM was found as $27.8 \%$ for the population aged 40 and above. The prevalence of MM among women was statistically significantly higher than the men, and the prevalence of MM in patients aged 65 years and older was $55.9 \%$ and significantly higher than below 65 years old. It was observed that individuals aged 65 years and over were more likely to visit the CPUs and hospitals in a year than the 40-65 age 
group. The most common disease in our study was hypertension found in $318(26.8 \%)$ patients. The number of chronic diseases in MM patients aged 65 years and over was higher than in the 40-64 age range, but no significant difference was found in increasing chronic disease numbers by sex.

Designing the prevalence studies of $\mathrm{MM}$ have some difficulties due to the existence of different definitions of $\mathrm{MM}$ and chronic diseases, different patient data sources. The number of patients included in the study, the age of patients, the number of diseases taken into account, the region where the study is done, the variety of data sources (date based on individual reports, questionnaires or medical record systems, etc.) lead to a variety of prevalence information (13). Different studies have been designed with different chronic disease codes in primary care. Hwang et al. consider 185 diseases and symptoms as chronic within 585 diagnostic codes, were identified in the ICD-9 (14). Taking these differences into consideration comparisons of the MM studies should be done with caution. As our study, some other studies in primary care settings accepted MM definition as 2 or more chronic diseases (15). We used ICPC-2 to characterize any disease as chronic disease (4).

The prevalence of MM was found $66.2 \%$ based on medical data of patients over 50 years of age enrolled in three PCUs in Ireland. The number of visits to the PCUs in a year increased in parallel with the number of chronic diseases (16). This finding is similar with our study. Brett et al. stated the prevalence of $\mathrm{MM}$ as $52 \%$. According to the age ranges of patients, the prevalence of MM was found to be 75,5\% for 45-64 years, 87,5\% for $65-74$ years and $97,1 \%$ for older than 75 years (17). In our study, prevalences in these ranges were as follows; $24.1 \%, 51 \%$ and $62.7 \%$. Brett et al. evaluated only the applicants, but we also selected the non-applied population to PCUs based on an online registry system listed to represent the whole population. Therefore, our study represented low prevalences. Although MM prevalence was studied previously, especially in developed countries, there are a limited number of studies for Turkey. Our study is the last study to determine the prevalence of MM in primary care, so the results are important in terms of giving an idea about the Turkish population.

In Switzerland, the study investigating the chronic disease patterns of MM patients, used ICPC-2, the rate of chronic diseases in MM patients was $74 \%$ hypertension, $31 \%$ diabetes and $29.1 \%$ ischemic heart disease (18). Differently, the first three common chronic diseases in our study were hypertension, diabetes and depression.

In the study of Gulbayrak et al., data of 3038 patients over 60 years of age who applied to a primary care unit were screened from polyclinics, and as a result $51.2 \%$ of patients had chronic disease and $5.1 \%$ had comorbidities (19). But, in this study there was no randomisation and the study population based on patients visited PCUs. Since our study has a representative sample, our results reflect prevalence more precisely. In our study, the rate of $\mathrm{MM}$ was found $77.3 \%$ and the prevalence of 3 most common diseases were hypertension 168 $(62.9 \%)$, diabetes $57(21.3 \%)$ and ischemic heart disease $46(17.2 \%)$ in patients 65 years old and over.

In 2011, 'The Prevalence and Risk Factors of Chronic Diseases Study in Turkey' determined the prevalence of hypertension as $24 \%$, diabetes mellitus 11\%, and hyperlipidemia $11.2 \%$ (9). According to the TURDEP-2 study, the prevalence of hypertension was $25.6 \%$ and the frequency of diabetes was $13.7 \%$ (10). It can be emphasized that our hypertension and diabetes prevalence are similar to 'The Prevalence and Risk Factors of Chronic Diseases Study in Turkey' and TURDEP-2 studies.

According to the data of the Ministry of Health, patients are admitted to a health care units on average 8.2 times in a year (2.9 times for PCUs, 5.3 for hospitals) and multimorbid patients had more visits in PCUs (mean: 7.01 vs 1.6) and hospitals (mean: 5.5 vs 2.1) within a year compared to non-multimorbid patients (20). Our results showed that the patients visited the health care units with a total of 6.05 times within a year (3.05 times to PCU and 3.00 to the hospital) which were less than the data of the Ministry of Health. These differences may be the cause of our methods of getting patients data.

According to our study, the frequency of MM is not to be neglected in our population. Parallel to the increasing frequency of MM, the responsibility of PCPs have increased in multimorbid patients' follow-up.

The current approach, based on the partial handling of multiple chronic diseases by different experts in hospital settings, is expensive and burdensome. Also, hospital based approaches with various medical specialities have uncertain benefits, and also have potential to cause harmful effects to multimorbid patients (21)

Effective primary care reduces the risk of hospitalization by preventing impairment of health, so it helps to control acute disease periods and to cope with chronic conditions (22). PCPs should better manage this situation in principles of family medicine (23).

It was stated that a care model focusing on eradication of disease and decrease of mortality have not fit very well to the management of chronic diseases. The researchers therefore proposed a 'goal-oriented care' approach, which encourages each individual to reach the highest levels of health care as defined by patients (24). Goal-oriented approach is very important for MM, because when the to-do list becomes too long and complex, it is necessary to make a ranking of importance with 
multimorbid patients. This approach strengthens competencies rather than eliminating insufficiencies, which stimulates the patient's selfmanagement and induces to get better by putting resistance instead of anxiety. This is the most rational and appropriate way to determine the patient's own goals. The task that is difficult to achieve in a goal-oriented approach is to find suitable ways for the patient to discover his treatment goals. One of the important challenges for PCPs is to explain the concept of goal-oriented care to colleagues, patients and their relatives. PCPs should also have to overcome the effects of a cultural and political climate where ordinary people are hard to hear in a health system which focuses on diseases more than the patients (25).

The chronic diseases management should start in the medical school training and continue by updating according to the requirements in practice after graduation. Besides the basic and clinical knowledge, effective communication skills and counseling, patient advocacy, and skills to be used to create behavioral change in society should be developed.

In management of the chronic disease, a team consisting of PCPs and allied health professions including the nurse, dietitian and psychologist should work together to improve care and ensure changes in the health behaviors of chronic patients. Therefore, the structure of primary care should be redesignated as multi-professional teams for the management of chronic diseases (9). follows;

The limitations of our study can be listed as

- Since the basis of our data is the diagnostic codes entered in the registration system, it was not possible to obtain confirmation from the patient or the physician.

- Diagnosis based on electronic records filled by PCPs. We were not able to check accuracy of the given diagnosis.

- Our results reflect only the Uskudar district of Istanbul and can be generalized to the whole Turkey but to many similar urban districts like Uskudar.

\section{CONCLUSION}

Approximately, one of four patients, and more than half of those with a chronic disorder, have MM. The main reasons why MM has gained importances are the ageing of population and financial pressures by increasing MM. The challenges associated with MM have become more visible, and now, the management of multimorbid patients are more important than yesterday. The current approach, based on the partial handling of multiple chronic diseases by different specialists in hospital settings, is expensive and burdensome. PCPs handle multimorbid patient's problems and overcomes responsibilities with a holistic and patient-centered approach, which are included in characteristics of family medicine. So, primary care should be strengthened and taken to ensure that each MM patient can access PCPs. Indeed, even in a health system where patients have direct access to medical specialists, PCPs should play a key role as coordinator for multimorbid patients. In conclusion, the structure of primary care should be redesigned for the management of multimorbid patients including 'goal-oriented care' approach and giving the responsibility of coordination of care to family physicians.

\section{REFERENCES}

1. World Health Organization (WHO). Multimorbidity: Technical Series on Safer Primary Care. Geneva: World Health Organization. Licence: CC BY-NC-SA 3.0 IGO, 2016. p. 3. Available from: https://apps.who.int/iris/bitstream/handle/10665/252275/9789241511650-eng.pdf?sequence $=1$

2. Le Reste J, Nabbe P, Manceau B, Lygidakis C, Doerr C, Lingner H, et al. The European General Practice Research Network Presents a Comprehensive Definition of Multimorbidity in Family Medicine and Long Term Care, Following a Systematic Review of Relevant Literature. J Am Med Dir Assoc. 2013;14(5):319325.

3. World Health Organization (WHO). Noncommunicable diseases (internet). 2021 April ( cited 2021 June 20). Available from: https://www.who.int/news-room/fact-sheets/detail/noncommunicable-diseases

4. O' Halloran J, Miller G, Britt H. Defining Chronic Conditions for Primary Care with ICPC-2. Fam Pract. 2004;21(4):381-86.

5. Wallace E, Salisbury C, Guthrie B, Lewis C, Fahey Tom, Smith SM. Managing patients with multimorbidity in primary care. BMJ. 2015;350:h176.

6. Barnett K, Mercer SW, Norbury M, Watt G, Wyke S, Guthrie B. Epidemiology of multimorbidity and implications for health care, research, and medical education: a cross-sectional study. Lancet. 2012; 380(9836): 37-43.

7. Rizza A, Kaplan V, Senn O, Rosemann T, Bhend H, Tandjung R. Age and gender-related prevalence of multimorbidity in primary care: the Swiss FIRE Project. BMC Fam Pract. 2012;24(13):113.

8. Van den Akker M, Buntinx E, Knottnerus JA. Comorbidity or multimorbidity: what's in a name? A review of literature. Eur J Gen Pract. 1996;2: 65-70.

9. Public Health Agency of Turkey. The prevalence study of chronic diseases and risk factors in Turkey. 2013. Presidency of Refik Saydam Health Center. Directorate of Hifzıssiha Institution. 
10. Satman I, Omer B, Tutuncu Y, et al. TURDEP-II Study Group. Twelve-year trends in the prevalence and risk factors of diabetes and prediabetes in Turkish adults. Eur J Epidemiol. 2013;28(2):169-80.

11. Fortin M, Stewart M, Poitras ME, Almirall J, Maddocks H. A Systematic Review of Prevalence Studies on Multimorbidity: Toward a More Uniform Methodology. Ann Fam Med. 2012;10(2):142-51.

12. Urbaniak GC, Plous S. Research Randomizer (Version 4.0) 2013. [Computer software]. Retrieved on June 22, 2013. Available from: http://www.randomizer.org/

13. Smith MS, Soubhi H, Fortin M, Hudon C, O’Dowd T. Managing patients with multimorbidity: systematic review of interventions in primary care and community settings. BMJ. 2012; 345.

14. Hwang W, Weller W, Ireys H, Anderson G. Out-of-pocket medical spending for care of chronic conditions. Health Aff (Millwood). 2001;20 (6): 267-78.

15. Cassell A, Edwards D, Harshfield A, Rhodes K, Brimicombe J, Payne R, et al. The epidemiology of multimorbidity in primary care: a retrospective cohort study. Br J Gen Pract. 2018;68(669):e245-e251.

16. Glynn LG, Valderas JM, Healy P, Burke E, Newell J, Gillespie P, et al. The prevalence of multimorbidity in primary care and its effect on health care utilization and cost. Fam Pract. 2011;28(5); 516-23.

17. Brett T, Arnold-Reed DE, Popescu A, Soliman B, Bulsara MK, Fine H, et al. Multimorbidity in patients attending 2 Australian primary care practices. Ann Fam Med. 2013; 11(6): 535-42.

18. Déruaz-Luyet A, N'Goran AA, Senn N, Bodenmann P, Pasquier J, Widmer D, et al. Multimorbidity and patterns of chronic conditions in a primary care population in Switzerland: a cross-sectional study. BMJ Open 2017;7:e013664.

19. Gülbayrak C, Açık Y, Oğuzöncül F, Deveci E, Ozan T. Yenimahalle Eğitim Araştırma Sağlık Ocağına Başvuran Yaşlılardaki Kronik Hastalıkların Sıklığı ve Maliyeti. Eurasian J Med,2003;35: 7-12.

20. Republic of Turkey Ministry of Health. News Bulletin of 2013 for Annual Health Statistics. 2014. [cited $2020 \mathrm{Feb} 5$ ]. Available from: https://dosyasb.saglik.gov.tr/Eklenti/2774,siy2013haberbultenipdf.pdf?0

21. Tinetti ME, Fried TR, Boyd CM. Designing health care for the most common chronic conditionmultimorbidity. JAMA. 2012;307(23):2493-94.

22. Billings J, Zeitel L, Lukomnik J, Carey TS, Blank AE, Newman L. Impact of socio-economic status on hospital use in New York City. Health Aff (Millwood). 1993;12(1):162-73.

23. Salisbury C. Multimorbidity: redesigning health care for people who use it. Lancet. 2012;380(9836):7-9.

24. Mold JW, Blake GH, Becker LA. Goal-oriented Medical Care. Family Medicine. 1991;23:46-51.

25. Lenzen SA, Daniëls R, van Bokhoven MA, van der Weijden T, Beurskens A. Setting goals in chronic care: Shared decision making as self-management support by the family physician. Eur J Gen Pract. 2015;21(2):138-44. 